(C) 1988 ISIJ

IIIIIIIIIIIIIIIIII

寄 春

IIIIIIIII!I!I!"
溶鉄中への吹込みによるダストの再利用の

可能性
川上 正博 ${ }^{*} \cdot$ 北島 要春 ${ }^{* 2} \cdot$ 伊藤 公允 ${ }^{*}$

\title{
Possibility of Dust Recycling Technique by the Injection into Molten Iron
}

Masahiro KaWAKamI, Youharu KITAJIMA and Koin ITO

\section{1. 緒}

\section{言}

電気炉製鎆では種々のスクラップを用いるため, 発生 するダスト中には, 酸化鉄はもとより, 非鉄金属の酸化 物が含まれている。これをそのまま電気炉にもどすこと は, スラグの粘性が上がる等, 操業上, 望ましくない. しかし，そのままで投棄することも，環境保全上，望ま しくない.この電気炉ダストの処理方法としては, 溶涬 中に溶かして無害化したのち投棄することや，アーク炉 を用いた還元回収法等が試みられている.

本研究では, ダストを溶鉄中に底吹きすることにより, 溶鉄中の $\underline{\mathrm{C} p ~} \mathrm{Si} て ゙$ 還元することを試みた．更に，その 際，廃ガス系への空気の混入を防ぐことにより，非鉄金 属成分の金属状での凝集回収を試みた。

\section{2. 実 験 方 法}

\section{$2 \cdot 1$ 実験装置}

実験装置の概略は前報1) と同じである．ただし，2次 ダストの捕集を行う場合は, 高アルミナ質の炉蓋の中央 部に石英製の煙突をとりつけ, 炉上部と蓋, および, 蓋 と煙突の間の間隙は, すべて,アルミナセメントで密封 した. 2 次ダストは煙突内で捕集した。捕集器は内径 $28 \mathrm{~mm} \phi$ の黄銅製の管，および，エルボーから成つてお り，中央部はフランジにより着脱可能とし，その中に約 $6 \mathrm{~g}$ のグラスウールを詰めた.

\section{$2 \cdot 2$ 供試材および実検条件}

原料鉄は鋳物用銑 1 種 1 号 B $(4 \% \mathrm{C}, 2 \% \mathrm{Si}, 0.5 \%$ $\mathrm{Mn}$ )である. 原料ダストは電気炉工場ダスト（平均粒 径 $2.5 \mu \mathrm{m}$, 標準偏差 $1.5 \mu \mathrm{m}$ ) で，その組成を Table 1 に示す.ダスト Cは，ダスト Bに $\mathrm{ZnO}$ の粉末試薬を添 加し, Zn 含有量を富化したものである. ダストは吹込 み前に十分乾燥した。実験条件の一覧を Table 2 に示 す.

\section{$2 \cdot 3$ 実検探作}

炉底部のノズルより $\mathrm{N}_{2}$ を吹き込みながら，約 $20 \mathrm{~kg}$ の原料鉄を溶解し, 温度を約 $1500^{\circ} \mathrm{C} に$ 安定させた.

溶鉄の初期試料を, 石英管で吸引採取し, ダストの吹込

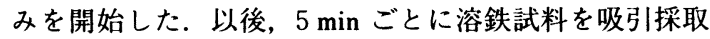

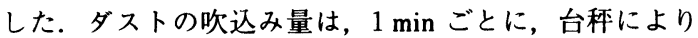
測定した. No. 7,8 の実験では，2次ダスト捕集器のエ ルボー下部の黄銅管を石英製煙突内に挿入し，他端を電 気掃除機に接続し，2次ダストを吸引捕集した。

溶鉄試料中の $\mathrm{C} は$ 燃焼法により，また， $\mathrm{Si}$ は二酸化 珪素重量法により分析した。 2 次ダストは, いつたん, 塩酸に溶解し, ICP (Induction Coupled Plasma) による 発光分光分析法により，分析した.

\section{3. 実験結果および考察}

\section{$3 \cdot 1$ ダスト量, $\mathrm{C}$ と $\mathrm{Si}$ 含有量の経時変化}

ダストAを用いた一例として，No. 4 の実験結果を

Table 1. Composition of the injected dusts (wt\%).

\begin{tabular}{lccccccccccc}
\hline & $\mathrm{Fe}_{2} \mathrm{O}_{3}$ & $\mathrm{FeO}$ & $\mathrm{SiO}_{2}$ & $\mathrm{CaO}$ & $\mathrm{MgO}$ & $\mathrm{MnO}$ & $\mathrm{Al}_{2} \mathrm{O}_{3}$ & $\mathrm{ZnO}$ & $\mathrm{PbO}$ & $\mathrm{CdO}$ & $\mathrm{H}_{2} \mathrm{O}$ \\
\hline Dust A & 27.1 & 1.93 & 8.03 & 5.66 & 19.31 & 9.49 & 1.40 & 5.29 & 1.24 & 0.026 & $\mathrm{Bal}$ \\
Dust B & 42.7 & 6.30 & 4.68 & 5.95 & 7.03 & 4.72 & 1.10 & 6.51 & 1.39 & 0.026 & Bal. \\
Dust C & 41.0 & 6.05 & 4.49 & 5.71 & 6.75 & 4.53 & 1.06 & 10.44 & 1.34 & 0.025 & $\mathrm{Bal}$. \\
\hline
\end{tabular}

昭和 59 年 10 月本会講演大会にて発表 昭和 62 年 11 月 6 日受付 (Received Nov. 6, 1987)

* 豊橋技術科学大学工博 (Toyohashi University of Technology, 1-1 Hibarigaoka, Tempaku-cho Toyohashi 440)

*2 豊橋技術科学大学大学院 (現: (株)不二越) (Graduate Shool, Toyohashi University of Technology, Now Nachi-Fujikoshi Corp.)

Key words : smelting reduction ; electric arc furnace dust ; dust recycling ; injection into molten iron ; zinc recovery ; cadmium recovery. 
Table 2. Experimental conditions.

\begin{tabular}{c|c|c|c|c|c}
\hline Run No. & Dust & $\begin{array}{c}\text { Dust feeding rate } \\
(\mathrm{g} / \mathrm{min})\end{array}$ & $\begin{array}{c}\text { Cas flow rate } \\
(\mathrm{Nl} / \mathrm{min})\end{array}$ & $\begin{array}{c}\text { Temperature range } \\
\left({ }^{\circ} \mathrm{C}\right)\end{array}$ \\
\hline 3 & A & 16.0 & 20 & $1500 \pm 25$ \\
$(\mathrm{~kg})$
\end{tabular}

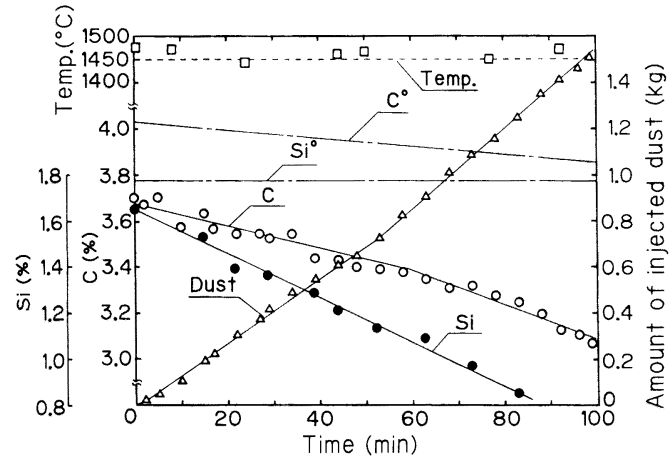

Fig. 1. Changes in the amount of injected dust, $[\% \mathrm{C}],[\% \mathrm{Si}]$ and temperature with time in Run No. 4 and 6 .

Fig. 1 に示す.ダストの吹込み速度は, 所定時間内で はほほ一定に保たれ，53 min までは $13.6 \mathrm{~g} / \mathrm{min}$ ，それ 以後 $100 \mathrm{~min}$ までは $17.4 \mathrm{~g} / \mathrm{min}$ であつた，総吹込み量 は $1.5 \mathrm{~kg}$ であつた。溶鉄中の $\mathrm{C} は ，$ 直線的に減少し， 脱炭速度は, ダストの吹込み速度に対応して, 増加した。 Si も初期の $1.66 \%$ から $100 \mathrm{~min}$ 後の $0.86 \%$ まで, 直 線的に減少した。なお，図中の一点鎖線で示した $\mathrm{C}^{0}$, $\mathrm{Si}^{0}$ は, ダストは吹き込まず， $\mathrm{N}_{2}$ のみを吹き込んだ No. 6 の実験結果である. $\mathrm{C}^{0}$ は $180 \mathrm{~min} て ゙ ~ 0.3 \%$ 減少 したが， $\mathrm{Si}^{0}$ は $1.9 \pm 0.05 \%$ でほぼ一定であつた. No. $3 \sim 6$ の実験では，炉蓋は耐火れんがを 2 個並べただけ であつたので, 空気が巻き込まれ，脱炭されたと考えら れる.

Fig. 2 には，ダストBを吹き込んだNo. 7 の実験結 果を示す。ダストの吹込み速度は 3 段階に変化させた。 Si は初期の $1.85 \%$ から約 $40 \mathrm{~min}$ で $0.1 \%$ 以下にほぼ 直線的に減少した． Cも直線的に隇少した．脱炭速度は ダストの吹込み速度が 50.3 から $67.3 \mathrm{~g} / \mathrm{min} に$ 増加し た時，大きくなつた。また，後者が 67.3 から 35.3 $\mathrm{g} / \mathrm{min}$ に減少した時, 前者は更に大きくなつたが, これ は，その時点で $\mathrm{Si}$ が還元剂として動かなくなつたため と考えられる。この実験では 2 次ダスト捕集のため, 空 気の遮断を注意深く行つたので, 空気による $\mathrm{C}, \mathrm{Si}$ の損 失はないと考えた。

ダストC を吹き込んだNo. 8 の実験結果は，ほぼ Fig. 2 と同様であつた.

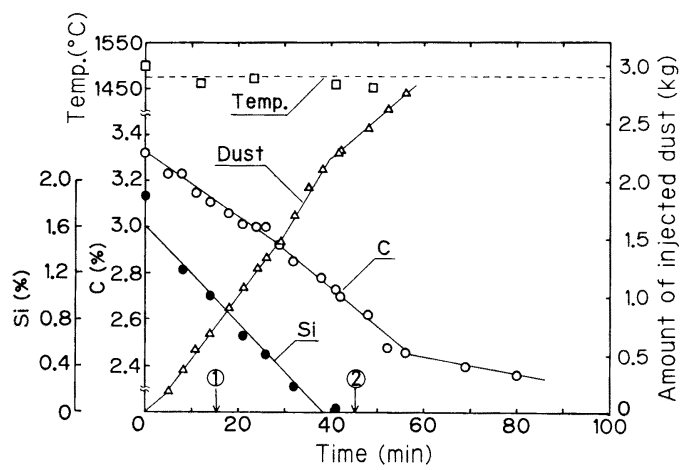

Fig. 2. Changes in the amount of injected dust, $[\% \mathrm{C}],[\% \mathrm{Si}]$ and temperature with time in Run No. 7.

\section{$3 \cdot 22$ 次ダストの捕集結果}

Fig. 2 中(1), (2)と印をつけた時点で 2 次ダストの捕 集を行つた．各捕集時間は $20 \mathrm{~s}$ とした．捕集中，煙突 から漏れ出るダストは観察されなかつた。 ダストの吹込 み速度は，長期的には一定と見なせたが，ごく短時間内 では，多少変動していた。そこで，捕集時のダストの吹 込み速度を, 捕集時の前後 $2 \mathrm{~min}$ の平均で求め, 2 次夕゙ ストの発生速度との関係を求めたところ，両者の間には ほぼ比例関係があつた。 その直線の傾きより，2次ダス 卜の発生速度はダスト吹込み速度の約 $1 / 5$ と見積もら れた。

Table 3 に，2次ダスト中の金属成分の分析結果を示 す。また，比較のために，吹き込んだダスト中の各成分 の分析值（金属分に換算）も示す. 2 次ダスト中の $\mathrm{Fe}$ 分は吹き込んだダスト中のものと比べ少なく，大部分は 鉄浴中に回収されたと考えられる.Mnは分析值として

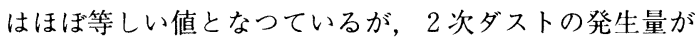
吹き込んだ量の $1 / 5$ となつているので，4/5 は鉄浴中に 回収されたと考えられる，Znと Cd は，おのおの，約 5 倍に濃縮されており，ほぼ完全に2 次ダスト中に回収 されたと考えられる．Pbの分析值は，吹き込んだダス トと 2 次ダストで，ほほ等しい值である． $\mathrm{Pb}$ の鉄浴へ の溶解度は小さいので ${ }^{2)}$ ，おそらくは， $\mathrm{Pb}$ は鉄浴の底 に別相として存在していたと考えられるが，確認はでき なかつた. $\mathrm{Pb}$ と $\mathrm{Zn}, \mathrm{Cd}$ との挙動の差は各金属の蒸気 圧の差淿によると考えられる. 
Table 3. Metallic composition of the collected dust and the injected dust (wt \%).

\begin{tabular}{c|rcccl}
\hline Sa. No. & \multicolumn{1}{|c}{ Fe } & $\mathrm{Zn}$ & $\mathrm{Mn}$ & $\mathrm{Pb}$ & $\mathrm{Cd}$ \\
\hline $7-1$ & 3.83 & 36.5 & 5.79 & 1.16 & 0.18 \\
$7-2$ & 7.73 & 29.6 & 4.38 & 0.62 & 0.11 \\
Dust B & 34.77 & 5.23 & 3.66 & 1.29 & 0.023 \\
\hline $8-1$ & 3.99 & 38.6 & 5.93 & 1.52 & 0.11 \\
$8-2$ & 4.74 & 43.0 & 3.93 & 1.33 & 0.15 \\
Dust C & 33.37 & 8.39 & 3.51 & 1.24 & 0.022 \\
\hline
\end{tabular}

2 次ダスト中のこれら金属成分は，（1)捕集したダス トの色が淡い青灰色か淡い褐色であつたこと，(2)煙突 の出口で, 空気による再酸化を思わせる暗赤色の炎が見 えたこと, ( 3 ) 分析操作で酸溶解する時, 多量の水素を 発生したこと, などより大部分は金属状であると判断し た。

\section{$3 \cdot 3$ ダストの還元率の推定}

ダストの成分中, $\mathrm{C}$ と $\mathrm{Si} て ゙$ 還元可能な酸化物は $\mathrm{Fe}_{2} \mathrm{O}_{3}, \mathrm{FeO}, \mathrm{MnO}, \mathrm{ZnO}, \mathrm{CdO}, \mathrm{PbO}$ である.これらの還 元可能な酸化物中の酸素の吹込み速度を $\dot{O}_{f}(\mathrm{~mol} / \mathrm{min})$ で表すと次式のようになる。

$$
\begin{aligned}
\dot{O}_{f} & =\frac{W_{P}}{1600}\left[\left(\% \mathrm{Fe}_{2} \mathrm{O}_{3}\right) \frac{3 M_{0}}{M_{\mathrm{Fe}_{2} \mathrm{O}_{3}}}+(\% \mathrm{FeO}) \frac{M_{0}}{M_{\mathrm{Feo}}}\right. \\
& +(\% \mathrm{MnO}) \frac{M_{0}}{M_{\mathrm{Mno}}}+(\% \mathrm{PbO}) \frac{M_{0}}{M_{\mathrm{Pbo}}} \\
& \left.+(\% \mathrm{ZnO}) \frac{M_{0}}{M_{\mathrm{Zno}}}+(\% \mathrm{CdO}) \frac{M_{0}}{M_{\mathrm{Cdo}}}\right] \ldots \ldots . .
\end{aligned}
$$

ここで， $W_{P}$ は $\mathrm{g} / \mathrm{min}$ で表したダストの吹込み速度，ま た， $M_{i}$ は物質 $i$ の原子量および $1 \mathrm{~g}$ 式量である.

一方, $1 \mathrm{~mol}$ の $\underline{\mathrm{C}} \mathrm{Si}$ は, おのおの, $1 \mathrm{~mol}$ と $2 \mathrm{~mol}$ の酸素と結合するので, 脱炭, 脱珪速度を $\Delta \dot{\mathrm{C}}, \Delta \dot{\mathrm{S}} \mathrm{i}$ $(\mathrm{mol} / \mathrm{min})$ で表せば，還元率 $R(\%)$ は

$$
R=\frac{\Delta \dot{\mathrm{C}}+2 \Delta \dot{\mathrm{S}} \mathrm{i}}{\dot{O}_{f}} \times 100
$$

で定義できる. $\Delta \dot{\mathrm{C}}$ および $\Delta \dot{\mathrm{Si}}$ は, 溶鉄の飛散損失量 $(2 \sim 3 \mathrm{~kg})$, および, 前述の空気酸化量の補正を行い, 更に吹き込んだ酸化鉄はすべて還元されたと仮定し，脱 炭, 脱珪の両速度より求めた. Table 4 に, 各実験での $\dot{O}_{f}, \Delta \dot{\mathrm{C}}, \Delta \dot{\mathrm{Si}}$ と $R$ をまとめて示す. No. 7 の 3 段目を除 き，還元率は $100 \%$ 以上となつており，吹き込んだ多 スト中の還元可能成分はすべて還元されたと考えられ る. No. 7の 3 段目では, Si がなくなつて，呾のみによ る還元となつたため，還元率が低下したと考えられる.

このように, Si による還元の方が優先的であり, $\Delta \dot{\mathrm{C}}$ と $\Delta \dot{\mathrm{Si}}$ の比で比べた $\mathrm{C} と ~ \underline{\mathrm{Si}}$ の還元寄与率は $2: 3$ から
Table 4. Oxide injection rate, oxidation rates of $\mathrm{C}$ and $\mathrm{Si}$ and the estimated degree of reduction.

\begin{tabular}{c|cccc}
\hline Run No. & $\dot{O}_{f}(\mathrm{~mol} / \mathrm{min})$ & $\Delta \dot{\mathrm{C}}(\mathrm{mol} / \mathrm{min})$ & $\Delta \dot{\mathrm{Si}}(\mathrm{mol} / \mathrm{min})$ & $R(\%)$ \\
\hline 3 & 0.163 & 0.090 & 0.069 & 140 \\
\hline 4 & 0.127 & 0.063 & 0.060 & 144 \\
& 0.162 & 0.069 & 0.060 & 117 \\
\hline 5 & 0.257 & 0.112 & 0.093 & 116 \\
\hline 7 & 0.653 & 0.187 & 0.286 & 116 \\
& 0.779 & 0.227 & 0.286 & 103 \\
& 0.459 & 0.302 & - & 66 \\
\hline 8 & 0.434 & 0.084 & 0.237 & 127
\end{tabular}

$1: 2$ 程度であつた。 なお, No. 3, 4 で還元率が異常に 高いのは, 溶鉄の飛散量や空気酸化量の見積りに誤差が あつたためと考えられる.

スラグの発生量は少なかつた. 実験終了後のスラグは 流動性に富んだ白涬であり，このことからも上記酸化物 はすべて還元されたと考えられる.

\section{4. 結言}

電気炉工場から発生するダストを溶鉄中に吹き込み, 各種酸化物の $\mathrm{C}, \underline{\mathrm{Si}}$ による還元を試み, 以下の結果を得 た。

(1) ダスト中の還元可能な酸化物成分である $\mathrm{Fe}_{2} \mathrm{O}_{3}$, $\mathrm{FeO}, \mathrm{MnO}, \mathrm{PbO}, \mathrm{ZnO}, \mathrm{CdO}$ はほほ $100 \%$ 還元回収され た.

( 2 )還元剤として, $\underline{\mathrm{C}}, \underline{\mathrm{Si}}$ 共に働いたが， $\underline{\mathrm{Si}}$ による還 元寄与率の方が大きかつた.

( 3 ) 吹き込んだダスト中の Zn と Cd は 2 次ダスト中 にほほ $100 \%$ 回収された。それらはほほ金属状であり, 高含有量であるので, 2 次ダストは $\mathrm{Zn}$ 製錬用原料とし て有望である.

以上より，本方法による電気炉ダストの再利用処理は 極めて有効な方法であると考えられる.

本研究は鉄鋼業環境保全技術開発基金の援助により遂 行された. ICP 分析では本学物質工学系の神野研究室 の援助をうけた。ここに記して謝意を表す.

\section{文献}

1 ) $M$. Kawakami, $H$. Yoshiga, Y. Kitajima, $M$. Noma and $K$. ITo: The Fifth Intern. Iron Steel Congress, Proc., Washington (1986), p. 751

2 ) $R$. P. ElLIOTT: Constitution of Binary Alloys, First Supplement (1965), p. 425 [McGraw-Hill]

3 ）講座・現代の金属学, 製錬編 2 , 非鉄金属製鍊（矢沢 涁編）（1980），p. 105 [日本金属学会] 


\section{Paraequilibrium and Orthoequilibrium}

Masato ENомото

\section{1. はじめに}

鉄合金のオーステナイト分解では，置換型合金元素の 分配の有無や变態モードに関してパラ平衡とオルソ平衡 という術語が用いられる。これらの言葉は今からおよそ 40 年前, HULTGREN ${ }^{1)}$ が当時の分析技術による測定結果 をもとに，母相オーステナイトと合金元素の濃度がほと んど差がないような変態生成相に対しては“パラ (Para)”, 合金元素の濃度が異なつている生成相には“才 ルソ (Ortho)”という接頭語（Prefix）を用いて区別し たことに始まる。変態生成相としてはフェライト，パー ライト, セメンタイト $\left((\mathrm{Fe}, \mathrm{X}){ }_{3} \mathrm{C}\right)$, あるいは $(\mathrm{Fe}$, $\mathrm{X})_{23} \mathrm{C} 6,(\mathrm{Fe}, \mathrm{X})_{7} \mathrm{C}_{3}$ などの合金炭化物が該当する。も ともとパラはギリシャ語で「側」「不正」「不規則」「疑似」, オルッは「真」「正」とかいつた意味である。 その後, この分野の研究が進展するにつれ，必ずしも分配の有る 無しといつた単純な 2 分法では対処しきれない変態モ一 ドが考えられるに及んで，研究者の間でこれらの用語の 意味が微妙に食い違うことも見られるようになつた。そ こで，本稿では用語の相違点に留意しながら，パラ平衡 とオルソ平衡の意味や性質を改めて考え直して見ること にする。

\section{2. パラ平衡と準安定平衡との関係}

HULTGREN のもともとの定義ではフェライトやセメン タイト中の置換型合金元素の濃度が母相のオーステナイ トとほとんど変わらない場合，これをパラフェライト， パラセメンタイト，あるいはパラパーライトと呼ぶ，パ ラ平衡では搪散速度の大きい炭素原子については生成相 と母相の間に化学平衡が成立しているが，鉄や置換型合 金元素の搪散はほとんど起こらないと考えられている. 従つて，令金元素を平衡量より余分に，あるいはそれ以 下しか含んで扔らず，無論，準安定相である。ここで, “Meta”ではなくあえて“Para”という接頭語を用いる
のは, 準安定が通常, 自由エネルギー極小に相当し, 小 さな濃度ゆらぎ，もしくは反応座標の増分に対して安定 であることを連想させるのに対し，パラ平衡は成分元素 の拡散が抑制されたための「部分平衡」であり，合金 元素の濃度変化に関しては, 自由エネルギーの極小には 対応していないことを示すためである2).ただし，準安 定という用語は最終平衡に相対して広く用いられてお り, 現在準安定と呼ばれているものの中に自由エネル ギー極小に対応しない相も含まれていることは大いにあ り得る。このようにパラ平衡は合金元素の拡散が全く起 こらないと想定した極限状態であつて, パラ平衡境界 $\left(\right.$ Para-boundary $\left.{ }^{2)}\right)$ はパラ変態相 (Paratransformation product $^{4)}$ ，あるいは Para-phase ${ }^{2)}$ ) が熱力学的に生成可 能な限界温度を示しているにすぎず，実際にそれらが生 成する限界温度と一致するとは限らない。

\section{3. パラ平衡モードと不分配局所平衡モード の相違}

パラ平衡モードによる成長とは母相と生成相の界面で 合金元素の化学ポテンシャルに段差が生じたまま界面が 移動を続けるという意味であり, 当初はパラフェライト, パラセメンタイトなどはこのモードによつて生成すると 考えられていた。ところが, HILLERT ${ }^{5)}$, COATES ${ }^{677)}$ によ りこのような段差が存在しなくても，言葉を代えれば, 化学ポテンシャルが界面で連続性を保ちながらでもパラ フェライトが生成しうることが示された。このモードは 不分配局所平衡 (Negligible-Partition Local Equilibrium, 略して NP-LE) モードと名付けられてい る. 界面における化学ポテンシャルの連続性を保つため には，低温では極端に薄い合金元素の拡散層（拡散スパ イク）の存在を想定しなければならないが，ともかく， パラフェライトが “界面に抒けるオルソ平衡”ともいう

† DARKEN ${ }^{3)}$ は部分平衡が多くの治金学的プロセスに適用できる重要な 概念であることを指摘している.

昭和 62 年 10 月 30 日受付 (Received Oct. 30, 1987)

* 金属材料技術研究所 Ph. D. (National Research Institute for Metals, 2-3-12 Nakameguro Meguro-ku, Tokyo 153)

Key words : paraequilibrium ; orthoequilibrium ; local equilibrium ; metastable equilibrium ; austenite decomposition. 
べき局所平衡モードによつて生成する可能性が指摘され たのである ${ }^{\dagger 2}$. オルソとパラの混乱の一因はここにあり， HILLERT はもともとの定義を最大限に生かす意味で, NP-LE モードによつて生成したフェライトを False para-ferrite, 合金元素の化学ポテンシャルが不連続な まま成長したフェライトを True paraferrite と呼ぶこ とを提案している2).

\section{4. 分配の最終段階という意味のオルソ}

生成相の合金元素濃度が母相と異なつている場合に, 当初これをオルソフェライト,オルソセメンタイト，あ るいはオルソパーライトと呼んだのであるが，その後， 成分元素の化学ポテンシャルがすべて等しいことを意味 する目的で使われることが多い，後者の場合これを界面 近傍だけに適用するか, あるいはバルクに適用するかに よつて大きな違いが生ずる. 界面近傍のオルソ平衡につ いては次節で検討を加えるとしてバルクのオルソ平衡に ついては以下の点を指摘しておきたい.

1 章で述べたようにオルソとは「真正」なという意味 であり, 究極的な平衡を連想させる. しかし, 細かく言 えば，オルソセメンタイトもグラファイトに対して準安 定相である. 従つて, この用法のオルソとは最終平衡相 であれ，準安定相であれ，合金元素のバルクの分配の度 合いが最終的な平衡に達した状態と解すべきである。核 生成理論において臨界核のパラ組成, オルソ組成といつ た用法9)はこれに属する.

\section{5. 局所平衡モードによる生成相を 意味するオルソ}

界面におけるオルソ平衡としての用法は,

「..... Orthoequilibrum refers to the case of complete local equilibrium at phase interfaces. On the other hand, paraequilibrium $\cdots \cdot . \cdot.\lrcorner^{8)}$

$\ulcorner$ ……この平衡をパラ平衡と名付けた. 一方, 合金元 素Mの分配が生じる場合は $\gamma / \alpha$ 界面で通常の平衡が成 り立つている場合であり,これをオルソ平衡と名付けた. 前者の場合には……」吕) (下線は筆者).

の他, かなり多くの研究者によつて行われているが, 問 題のある用法である.

Fig. 1 は局所平衡（分配局所平衡モード）による成 長の際の界面濃度を定める HILLERT の作図である.この 作図ではまず，バルク組成を通るオーステナイト中のC の等活量線を引く. 次に, この等活量線がオルソの $\gamma /(\alpha$ $+\gamma)$ 境界と交わる点 $(\mathrm{s})$ を通る Tie-line の他端 $(\mathrm{t})$ が このモードによつて生成するフェライトの組成を与え

† NP-LE モードに対し，局所平衡を保ちながら合金元素の分配を生 ずる変態モードを分配局所平衡（Partition Local Equilibrium, P-LE) モードと呼ぶ8). 一般に, 高温（低過冷度）では P-LE, 低 温（高過冷度）では NP-LE モードが偪き，両モードの間には理論 的には明瞭な遷移温度がある。

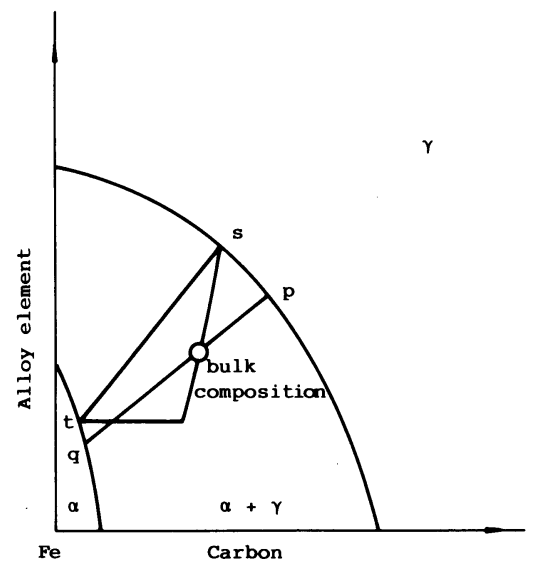

Fig. 1. Schematic illustration of the compositions at interphase boundaries during the growth of ferrite under local equilibrium ( $s$ and $t$ ) and the compositions at final equilibrirm ( $p$ and $q$ ).

る. 組成 $\mathrm{t}$ のフェライトはこの場合，合金元素を平衡量 ( q )以上に含む準安定相であり, 長時間熱処理を続けれ ば最終的な平衡濃度に達するはずである。

したがつて問題としては第一に分配の度合いが中間状 態にある相に対して, “オルソ”の語感が必ずしもよく なじまないこと，第二にこの用法では 3 章で触れたよう な低温の不分配局所平衡モードで生成したフェライトも オルソフェライトと呼ばなければならなくなることであ る. 後者の問題については接頭語を代えて混乱を避けよ うという提案があることは 3 章で述べた. 前者に関して は HILLERTによれば，準安定相であることは十分認識す るが, 最終平衡の意味に限定すると，そのような状態は ほとんど実現しないのでオルソという言葉が用いられな くなるおそれがあるとのことである11).

\section{6. パラ平衡とオルソ平衡の相境界の位置関係}

3 元以上の多元系でパラ平衡（もしくは部分平衡）と オルソ平衡（最終平衡）の相境界の間に何か一般的な性 質があれば，変態や相平衡関係を考察する上で指針とし て大いに役立つであろう。ここでは Fe-C-X 系の $\alpha / \gamma$ 平衡について等活量線を使つた作図法により,これら 2 種の平衡相境界の位置関係を検討してみよう．類似の考 察が以前, HILLERT ${ }^{2)} に よ り$ 行われていたが, 以下で述 べるのは詳細では異なつており, 筆者なりの説明を試み たものである.

はじめに, Xが Mn あるいは $\mathrm{Ni}$ のような $\gamma$-former である場合を考える：C漕度がぜロのときパラ平衡境界 はその定義から明らかなように $\mathrm{Fe}-\mathrm{X} 2$ 元系の $\mathrm{T}_{0}$ 組成 を与える. 一方, Xの濃度がぜロのときは, $\mathrm{Fe}-\mathrm{C} 2$ 元 


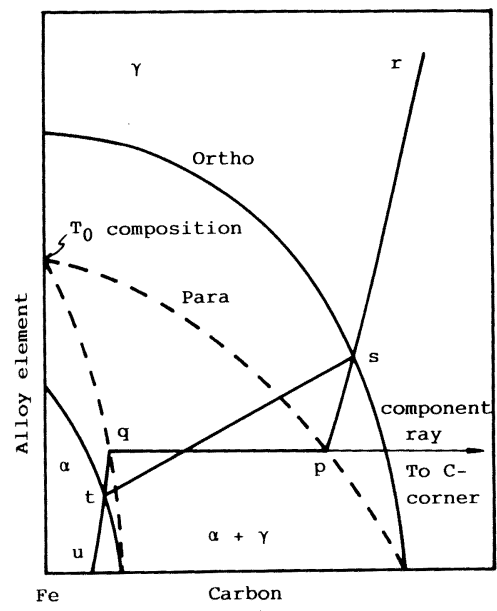

Fig. 2. Schematic illustration of $\alpha / \gamma$ ortho- and paraequilibrium phase boundaries in an $\mathrm{Fe}-\mathrm{C}-\mathrm{X}$ system in which $\mathrm{X}$ is an austenite former. rstu and rpqu are the carbon isoactivity lines of an identical activity value.

系の平衡相境界になる. 従つて, Fig. 2 に示すように, パラ平衡の $(\alpha+\gamma) 2$ 相域は $\mathrm{Fe}-\mathrm{C}$ 軸上に底辺を有する 三角形のような形状になり，帯状のオルソ平衡の 2 相域 に含まれることが直感的に理解されるが，このことは次 のようにしても確かめられる.

いま, Cの等活量線 ruを考え, ruがオルソ境界と $\mathrm{s}, \mathrm{t}$ で交わるとする. 等活量線は 2 相域では Tie-line となる. 同じ活量値の等活量線を $\mathrm{s}$ からパラ相境界まで 延長し，それとの交点を $\mathrm{p}$ とする. パラ平衡の Tie-line は C-corner から発せられる $\mathrm{Fe} / \mathrm{X}$ の比が一定の “Component ray”になつており,この Tie-line の他端 をqとすると， q を通るフェライト中の等活量線はオル ソ平衡で描いた等活量線 tu と一致するはずである。 パ ラ平衡の 2 相域がオルソ平衡の 2 相域の外側にあつては このような作図が不可能であることは明らかである.

Xが Si P Mo のように $\alpha$-former である場合にも Fig. 3 に示すように, パラの $(\alpha+\gamma) 2$ 相域がオルソよ り内側にくる場合にだけ, Fig. 2 と同様な等活量線の 作図を行うことができる. Fig. 3 はオーステナイト中 のCとXの相互作用が反発的であるような Xについての 作図であるが，吸引相互作用を有するXについても事情 は全く同じである，通常，2 元系でもセメンタイトとグ ラファイトのように準安定相の 2 相域は最終平衡相に比 ベ縮小しているが，上に述べたパラとオルソの 2 相域の 位置関係はこれと同等の事柄と見て差し支えないであろ う. 従つて, $\alpha$-former と $\gamma$-former を同時に含むような

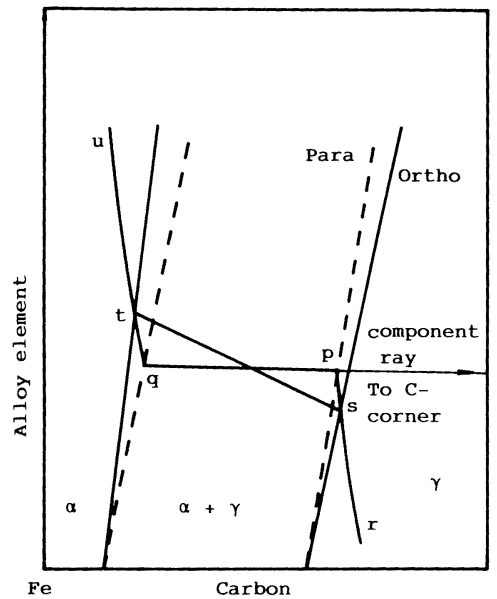

Fig. 3. Same figure as Fig. 2 for $\mathrm{X}$ of a ferrite former.

高次の多元系でも一般的にパラの 2 相域はオルソより縮 小していると考えられる.

HULTGREN が最初にオルソを定義した頃はまだ P-LE， NP-LE モードという認識はなく，単純に分配の有無を 区別するほどの意味であつた，従つて，彼の記述に最終 平衡を意味する場合と局所平衡を意味する場合とが混在 している11). また，相平衡を記述する場合と変態モー ドに関連して使われる場合とを混同することにより，パ ラ平衡の 2 相域で生成するのはパラフェライトであると いつた早吞込みの危険性も生じてくる. 数年来, これら の用語に悩まされ続けてきた一人として頭の整理を行つ てみると同時に, 読者諸氏に用語の意味をいつそうよく 理解していただくために筆をとつたしだいである。

\section{文献}

1 ) A. Hultgren: Trans. Am. Soc. Met., 39 (1947), p. 915

2 ) M. HiLlert: Internal Report, Swedish institute of Metal Research (1953)

3 ) L. S. Darken: Trans. Metall. Soc. AIME, 221 (1961), p. 654

4 ) A. Hultgren and collaborators: Kungl. Svenska Vetenskapsakademiens Handlinger., 4 (1953) 3, p. 3

5 ) M. HillerT: The Mechanism of Phase Transformations in Crystalline Solids (1969), p. 231 [Institute of Metals, London]

6 ) D. E. CoATEs: Metall. Trans., 3 (1972), p. 1203

7 ) D. E. CoATES: Metall. Trans., 4 (1973), p. 1077

8 ) D. E. CoAtes: Metall. Trans., 4 (1973), p. 2313

9 ) M. ENomoto and H. I. Aaronson: Metall. Trans. A, 17 (1986), p. 1381

10）宇都宮武志, 星野和夫, 佐久間健人, 須藤 一: 鉄と鋼, 73 (1987), p. 1582

11) M. HiLleRT (私信) 